\title{
Interactive effects of phosphorus and light availability on early growth of maritime pine seedlings
}

\author{
Alissar CHEAÏB ${ }^{\mathrm{a} *}$, Alain MOLLIER ${ }^{\mathrm{a}}$, Stéphane THUNOT ${ }^{\mathrm{a}}$, Catherine LAMBROT ${ }^{\mathrm{b}}$, Sylvain PELLERIN ${ }^{\mathrm{a}}$, \\ Denis LOUSTAU ${ }^{b}$ \\ a INRA, UMR TCEM (Transfert Sol-Plante et Cycle des Éléments Minéraux dans les Écosystèmes Cultivés), 71, avenue Edouard-Bourlaux, \\ BP 81, 33883 Villenave d'Ornon Cedex, France \\ b INRA, Unité EPHYSE (Écologie Fonctionnelle et Physique de l'Environnement), 69 route d'Arcachon, 33612 Gazinet, France
}

(Received 2 June 2004; accepted 29 April 2005)

\begin{abstract}
We examined the response of early growth of maritime pine seedlings to combined levels of light and phosphorus. Seedlings were grown under three levels of phosphorous availability, i.e., two relative addition rates $\left(R A R=2\right.$ and $\left.4 \mathrm{~g} \mathrm{P}\left(100 \mathrm{~g}^{-1}\right) \mathrm{P} \mathrm{d}-1\right)$ and a free-access to $\mathrm{P}$, crossed with two light levels (photosynthetic photon flux densities of 150 and $450 \mu \mathrm{mol} \mathrm{m}^{-2} \mathrm{~s}^{-1}$, respectively). Relative growth rate $(R G R)$ and relative uptake rate of phosphorus $(R U R)$ were computed, as well as the amount of light absorbed per seedling. We found that phosphorus and light acted as limiting factors with a complex interaction. Under low light and at the lowest P level, P and light were co-limiting, i.e., growth was enhanced only when $\mathrm{P}$ and light were increased together. Light was the limiting factor for growth under low light conditions at all other levels of $\mathrm{P}$ availability. $\mathrm{P}$ was the limiting factor at a RAR of $2 \%$ under high light. Enhancing P from $4 \%$ to free access did not significantly improve growth under high light. $R U R$ was controlled systematically by $\mathrm{P}$ availability at 2 and $4 \% R A R$. $R G R$ values were close to $R U R$ values except under free access to $\mathrm{P}$. Therefore, growth-independent accumulation of $\mathrm{P}$ was observed under high $\mathrm{P}$ conditions. The differences in biomass production among $\mathrm{P}$ treatments were explained primarily by the reduced amount of radiation intercepted by the seedlings as a consequence of their reduced leaf area. No effect of $\mathrm{P}$ treatments were observed on the calculated radiation-use efficiency (RUE), which was found to be larger under low light. This confirms that pine seedlings adjust to moderate phosphorus deficiency mainly by changing their morphology (leaf area, dry-mass partitioning) while biochemical and photochemical limitations of photosynthesis play only a very secondary role.
\end{abstract}

phosphorus nutrition / shade / growth / Pinus pinaster Aït.

Résumé - Interaction des effets de la disponibilité en phosphore et en lumière sur la croissance de jeunes plants de pin maritime. La croissance de jeunes plants de pin maritime a été suivie en chambre de culture à deux niveaux d'éclairement et trois de disponibilité en phosphore. Deux taux d'addition relatifs en $\mathrm{P}\left(R A R=2\right.$ et $4 \mathrm{~g} \mathrm{P}\left(100 \mathrm{~g}^{-1} \mathrm{P} \mathrm{j}^{-1}\right)$ et un libre accès au $\mathrm{P}$ ont été appliqués en combinaison avec deux niveaux d'éclairement (150 et $\left.450 \mu \mathrm{mol} \mathrm{m}^{-2} \mathrm{~s}^{-1}\right)$. Le taux de croissance relatif $(R G R)$ et le taux d'absorption relatif de $\mathrm{P}(R U R)$ ont été calculés. La surface foliaire, la quantité de rayonnement absorbé et l'efficience d'utilisation du rayonnement (RUE) ont aussi été estimés. Les disponibilités en phosphore et en lumière ont limité la croissance suivant un schéma d'interaction complexe. Au plus faible niveau d'éclairement et d'ajout en phosphore, les deux facteurs étaient co-limitants et la croissance n'était augmentée que lorsque les deux facteurs augmentaient simultanément. La lumière était le facteur limitant pour les traitements sous faible éclairement à tous les autres niveaux de disponibilité en P. Le phosphore était limitant pour des $R A R$ de $2 \%$ sous fort éclairement. Le taux de prélèvement relatif en $\mathrm{P}(R U R)$ était contrôlé par la disponibilité en $\mathrm{P}$ aux taux d'addition relatifs $(R A R)$ de 2 et $4 \%$. Les valeurs de $R G R$ étaient proches des valeurs de $R U R$ sauf au plus fort niveau de disponibilité en $\mathrm{P}$ où une accumulation de $\mathrm{P}$ indépendante de la croissance a été observée. La réduction de la croissance sous limitation en $\mathrm{P}$ est explicable par la réduction de la quantité de rayonnement absorbé par les plants, par suite d'une expansion limitée et plus lente de leur surface foliaire. Il n'y a pas eu d'effet de la disponibilité en P sur le RUE. Le RUE était par contre plus élevé sous faible éclairement. En conclusion, nos résultats confirment que les jeunes plants de pin maritime soumis à une déficience modérée en $\mathrm{P}$ ajustent leur croissance (réduction de l'expansion de la surface foliaire) sans effet majeur sur le $R U E$.

nutrition en phosphore / ombrage / croissance / Pinus pinaster Aït.

\section{INTRODUCTION}

In their natural habitat, forest species are exposed to multiple trophic constraints related to either climatic conditions such as water and light or nutrient availability in soils. Predicting their response to changes in the availability of a given resource or to combined changes in several resources is of critical importance in the context of global environmental changes. Many studies have been devoted to interactions between light and nitrogen in forest species [1, 7, 9, 16, 29]. These studies

* Corresponding author: acheaib@ bordeaux.inra.fr 
demonstrated the importance of interactive effects of nitrogen and light on regulating the physiology and growth of seedlings. For example, Elliott and White [16] demonstrated that high nitrogen significantly increased total biomass of red pine seedlings under high irradiance but had no effect in shade.

Studies on interactions between light and phosphorus are still scarce, although phosphorus is a common limiting factor for tree growth in natural environments [52, 57]. Increased growth in response to enhanced $\mathrm{P}$ availability was commonly reported for many tree species either in the field or under artificial growth conditions [9, 52, 55, 57]. Chang [9] showed that increasing $\mathrm{P}$ supply from 0 to $50 \mathrm{~kg} \mathrm{Pha}^{-1}$ increased basal diameter and height increment of two-month-old sweetgum seedlings by 24 and 22\%, respectively. Topa and Cheeseman [55] reported that after six weeks of aerobic solution culture, low$\mathrm{P}$ treatment $(5 \mu \mathrm{M} \mathrm{P})$ reduced Pinus serotina seedling dry weight, relative growth rate of shoots and roots by 39, 41 and $58 \%$, respectively. Tree growth response to light availability has been studied by many authors. Faster growth was reported under increased light availability for numerous hardwoods and conifers in both natural and greenhouse environments [12, 16, $47,58]$. Elliot and White [16] reported 4 to 5 times more biomass for red pine (Pinus resinosa Ait.) seedlings grown under high $\left(>800 \mu \mathrm{mol} \mathrm{m}{ }^{-2} \mathrm{~s}^{-1}\right)$ light than under low light $(190 \mu \mathrm{mol}$ $\mathrm{m}^{-2} \mathrm{~s}^{-1}$ ). On longleaf pine, Jose et al. [29] observed under high light a 48.6 and $56 \%$ increase of stem and root biomass, respectively. On four deciduous and pioneer species, Rincon and Huante [47] reported larger relative growth rates $(R G R)$ and biomass production under high light $\left(400 \mu \mathrm{mol} \mathrm{m} \mathrm{m}^{-2} \mathrm{~s}^{-1}\right)$ as compared with low light $\left(80 \mu \mathrm{mol} \mathrm{m}^{-2} \mathrm{~s}^{-1}\right)$.

Although separate effects of phosphorus and light availability on tree growth are well documented, there still is a lack of knowledge on how both factors interact. It has been demonstrated that a moderate deficiency in phosphorus first affects shoot growth and leaf development, whereas a pronounced deficiency depresses photosynthesis through a decrease in carboxylation and quantum efficiency [2, 5, 28, 33, 34]. Whereas the effects of phosphorus deficiency on photosynthesis have been investigated extensively at cell and leaf levels, the interaction between phosphorus availability and carbon accumulation at whole plant level is less documented.

The objectives of the present study were to assess how growth rate and biomass of a forest tree species are affected by different levels of light and phosphorus availability and whether some interactive responses to light and phosphorus limitation occur, particularly for phosphorus productivity $\left(\mathrm{P}_{\mathrm{P}}\right)$ and radiation-use efficiency $(R U E)$. The experiment was conducted on maritime pine (Pinus pinaster Aït.), a shade-intolerant species grown in southwestern Europe on soils characterised by a low phosphorus availability $[50,51]$. Numerous studies have reported a positive effect of $\mathrm{P}$ fertilization on maritime pine growth in this context $[21,54,56]$. Indeed, in field conditions, plant nutrient uptake is affected by biotic, e.g., mycorrhization [22] or abiotic factors, such as nutrient availability [18] or soil structure [41], which makes it difficult to study the specific effects of nutrient uptake on growth. In sake of simplicity and for enabling us to monitor the plant uptake rate of phosphorus, our experiment was therefore operated under hydroponic conditions where the nutrient addition rate is controlled accurately.

\section{MATERIALS AND METHODS}

\subsection{Plant material and growth conditions}

Seeds of maritime pine (Pinus pinaster Aït) originating from the Landes of Gascogne forest (Southwestern France) were disinfected with a solution of $4 \% \mathrm{CaCl}_{2}$ for $10 \mathrm{~min}$ and then germinated in containers filled with moistened vermiculite. The containers were placed in a climate chamber with light supplied by $250 \mathrm{~W}$ HQI lamps ( $16 \mathrm{~h}$ day, $8 \mathrm{~h}$ night). Photosynthetic photon flux density (PPFD) measured at the plant level was $230 \mu \mathrm{mol} \mathrm{m}^{-2} \mathrm{~s}^{-1}$. Air temperature and relative humidity were $20^{\circ} \mathrm{C}$ day $/ 15^{\circ} \mathrm{C}$ night and $70 \%$, respectively. Containers were irrigated daily and treated weekly with a fungicide (cryptonol, $0.3 \%)$.

Thirty days after sowing (DAS), 216 seedlings were selected on the basis of their overall uniformity (mean total fresh weight: $0.184 \mathrm{~g}$ per seedling) and transplanted into aeroponic growth units (Biotronic, Uppsala, Sweden). The aeroponic growth units were automated to control the composition of the nutrient solution that was continuously recycled and sprayed on the root systems according to the specifications prescribed by Ingestad and Lund [26].

Each growth unit received 36 seedlings. Except for P, the composition of the nutrient solution was adapted from the recommendations given for Pinus sylvestris by Ingestad [24] (Tab. I). Details about P supplied to the plants are given later in the text. The $\mathrm{pH}$ of the nutrient solution was maintained between 4.0 and 4.5 by regular acid or basic P-free nutrient solution additions.

Six growth units corresponding to six treatments were randomly arranged in a growth chamber with the following climate: $16 \mathrm{~h}$ day/ $8 \mathrm{~h}$ night, $20-23{ }^{\circ} \mathrm{C}$ day $/ 15-18^{\circ} \mathrm{C}$ night and $70 \%$ relative humidity. Light was supplied by $250 \mathrm{~W}$ metal-halide lamps (TD 70/150/250, MAZDA, Belgium). The experiment was conducted between July 23 and October 25, 2002.

\section{2. $P$ and light treatments}

Three rates of $\mathrm{P}$ supply (high $\mathrm{P}$, intermediate $\mathrm{P}$ and low $\mathrm{P}$ ), combined with two levels of irradiance (high light: PPFD of 400-500 $\mu \mathrm{mol}$ $\mathrm{m}^{-2} \mathrm{~s}^{-1}$ and low light: PPFD of $120-180 \mu \mathrm{mol} \mathrm{m}^{-2} \mathrm{~s}^{-1}$ ) were applied between seedling transplantation (30 DAS) and the end of the experiment (105-110 DAS). In the high P treatment (HP, or free-access), $\mathrm{P}$ was supplied as $\mathrm{KH}_{2} \mathrm{PO}_{4}$ at a growth-saturating concentration of 516 $\mathrm{mM}$ P. For intermediate (IP) and low (LP) treatments, $\mathrm{P}$ was supplied at a daily relative addition rate $(R A R)$ of 4 and $2 \mathrm{~g} \mathrm{P}\left(100 \mathrm{~g}^{-1}\right) \mathrm{P} \mathrm{d}^{-1}$, respectively [26]. Assuming the relative growth rate, $R G R$, was close to the relative addition rate, $R A R$, the amount of $\mathrm{P}$ added at day $\mathrm{t}\left(\mathrm{P}_{\mathrm{A}}\right)$ into the nutrient solution was calculated as:

$$
P_{A}=P_{S}\left[\exp { }^{\left(\frac{R G R}{100}\right)}-1\right]
$$

where $P_{\mathrm{S}}$ is the amount of $\mathrm{P}$ in seedlings on day $\mathrm{t}$, and $R G R$ the relative growth rate of the seedlings in each growth unit. In the LP and IP treatments, nutrient solution conductivity was adjusted to $80-150 \mu \mathrm{S} \mathrm{cm}^{-1}$ by addition of $\mathrm{P}$ free nutrient solution. In the free-access treatment (HP), nutrient solution conductivity was adjusted to $300-350 \mu \mathrm{S} \mathrm{cm}^{-1}$ by the addition of nutrient solution containing $\mathrm{P}$. A high conductivity value was chosen to maintain a high $\mathrm{P}$ concentration in the nutrient solution of the free-access treatment (HP).

The low irradiance level was obtained by shading plants with four layers of white cloth, whereas seedlings subject to high light treatment were exposed to unobstructed light. Homogeneity of irradiance within each growth unit was checked with a PPFD light sensor (Li-190 SB, Licor ltd, Lincoln USA). The resulting photosynthetic photon flux 
Table I. Composition of the stock nutrient solutions (mM).

\begin{tabular}{|c|c|c|c|c|}
\hline \multirow[t]{2}{*}{ Compound } & \multicolumn{2}{|c|}{ Basic solution } & \multicolumn{2}{|c|}{ Acid solution } \\
\hline & P-free & With P & P-free & With P \\
\hline $\mathrm{NH}_{4}$ & 5593 & 5714 & 0 & 0 \\
\hline $\mathrm{NO}_{3}$ & 1550 & 1429 & 7143 & 7143 \\
\hline $\mathrm{P}$ & 0 & 516 & 0 & 516 \\
\hline K & 1151 & 1151 & 1151 & 1151 \\
\hline $\mathrm{Ca}$ & 150 & 150 & 150 & 150 \\
\hline $\mathrm{Mg}$ & 247 & 247 & 247 & 247 \\
\hline S & 250 & 250 & 250 & 250 \\
\hline $\mathrm{Fe}$ & 0.7 & 0.7 & 0.7 & 0.7 \\
\hline $\mathrm{Mn}$ & 4 & 4 & 4 & 4 \\
\hline $\mathrm{Cu}$ & 0.03 & 0.03 & 0.03 & 0.03 \\
\hline $\mathrm{Zn}$ & 0.06 & 0.06 & 0.06 & 0.06 \\
\hline B & 0.2 & 0.2 & 0.2 & 0.2 \\
\hline Mo & 0.007 & 0.007 & 0.007 & 0.007 \\
\hline $\mathrm{Na}$ & 0.22 & 0.22 & 0.22 & 0.22 \\
\hline $\mathrm{Cl}$ & 0.033 & 0.033 & 0.033 & 0.033 \\
\hline
\end{tabular}

density (PPFD) at the top of the seedlings was 120-180 and 400$500 \mu \mathrm{mol} \mathrm{m}^{-2} \mathrm{~s}^{-1}$ for the LL and HL treatments, respectively.

\subsection{Plant measurements and chemical analysis}

Three plants per treatment were sampled each week for a nondestructive measurement of the total fresh weight per seedling and calculation of the relative growth rate $(R G R)$. Each plant was carefully removed from the growth unit, and hanged on a wooden frame. The root system was blotted dry between absorbing papers before the seedling was weighed. Plants were subsequently replaced in their growth unit. Additionally, three plants per treatment were randomly sampled every $15 \mathrm{~d}$ for measuring dry weight at $65^{\circ} \mathrm{C}$ of shoot and root, as well as the total $\mathrm{P}$ content of the seedling. Five plants per treatment were harvested at 68,88 and 105-110 DAS for morphologic measurements. Length, width and dry weight of three euphylls (the "primary needles" for maritime pine seedlings, see [31,40]) of the main stem and auxiblasts (the axillary shoots which have the same structure than the main shoot) were measured. The area and area-to-mass ratio of individual euphylls were subsequently calculated. The total euphyll area was estimated from the area-to-mass ratio of individual euphylls and the total euphyll dry weight. The same procedure was used to estimate the pseudophyll (two "secondary needles" which compose the brachyblasts, see $[31,40])$ area. The total foliage area per plant was calculated by summing euphyll and pseudophyll areas. The remaining shoot and root system were dried at $65^{\circ} \mathrm{C}$, weighed and $\mathrm{N}$ and $\mathrm{P}$ contents measured colorimetrically with a Technicon Autoanalyser II [43].

\subsection{Control of environmental conditions}

The photosynthetic photon flux density (PPFD) was measured continuously for each growth unit at the level of seedlings using amorphous silicon cells (Solems, France) as proposed by Chartier et al. [11]. Air and nutrient solution temperatures of each growth unit were monitored using $\mathrm{Cu}-\mathrm{Cr}$ thermocouples recorded with a datalogger (CR23X, Campbell Scientific France, Paris). Relative humidity in the chamber was measured with a relative humidity probe (HMP35AC, Campbell Scientific). Air and nutrient temperatures, as well as humidity meas-
Table II. Mean and standard deviation of diurnal air and nutrient solution temperatures $\left({ }^{\circ} \mathrm{C}\right)$ and incident PPFD $\left(\mu \mathrm{mol} \mathrm{m} \mathrm{m}^{-2} \mathrm{~s}^{-1}\right)$ for each treatment during the experimental period ( $n=74-94$ days).

\begin{tabular}{lccc}
\hline & $\begin{array}{c}\text { Air } \\
\left({ }^{\circ} \mathrm{C}\right)\end{array}$ & $\begin{array}{c}\text { Nutrient solution } \\
\left({ }^{\circ} \mathrm{C}\right)\end{array}$ & $\begin{array}{c}\text { PPFD } \\
\mu \mathrm{mol} \mathrm{m}^{-2} \mathrm{~s}^{-1}\end{array}$ \\
\hline $\begin{array}{l}\text { Treatments } \\
\text { LL-LP }\end{array}$ & $22.3 \pm 1.3$ & $21.0 \pm 1.5$ & $184 \pm 17$ \\
LL-IP & $21.5 \pm 1.2$ & $23.0 \pm 1.3$ & $157 \pm 11$ \\
LL-HP & $21.0 \pm 1.3$ & $24.1 \pm 1.5$ & $122 \pm 26$ \\
HL-LP & $22.3 \pm 1.4$ & $21.8 \pm 1.3$ & $410 \pm 23$ \\
HL-IP & $24.0 \pm 1.2$ & $22.3 \pm 1.0$ & $501 \pm 26$ \\
HL-HP & $22.0 \pm 1.4$ & $22.8 \pm 1.8$ & $424 \pm 46$ \\
\hline
\end{tabular}

urements, were performed every $10 \mathrm{~min}$ and hourly and average values computed. The average daily values of climatic conditions corresponding to each treatment are shown in Table II. As expected, PPFD differed between low (120 to $180 \mu \mathrm{mol} \mathrm{m}^{-2} \mathrm{~s}^{-1}$ ) and high light (410 to $500 \mu \mathrm{mol} \mathrm{m} \mathrm{m}^{-2} \mathrm{~s}^{-1}$ ). Although air in the growth chambers was stirred, average air temperature differed slightly among growth units and treatments. To account for these differences, growth kinetics were expressed on a thermal time basis $\left(T T,{ }^{\circ} \mathrm{C}\right.$ days) calculated on a daily basis as follows:

$$
T T=\sum\left[\frac{\left(T_{\mathrm{X}}+T_{\mathrm{N}}\right)}{2}-T_{\mathrm{b}}\right]
$$

where $T_{\mathrm{X}}$ is the maximum daily air temperature $\left({ }^{\circ} \mathrm{C}\right), T_{\mathrm{N}}$ the minimum daily temperature $\left({ }^{\circ} \mathrm{C}\right)$ and $T_{\mathrm{b}}$ the base temperature. Since no reference exists in the literature about the base temperature for maritime pine, an arbitrary value of $T_{\mathrm{b}}=10{ }^{\circ} \mathrm{C}$ was used for calculations. All measured temperatures were above this base value so that this arbitrary choice may alter the absolute values of calculated thermal time but not the relative values between treatments. 


\subsection{Calculations and statistics}

To account for the temperature difference observed between growth units, the individual relative growth rate of each seedling $(R G R$ in $\left.\mathrm{g} \mathrm{g}^{-1}\left({ }^{\circ} \mathrm{C} \text { days }\right)^{-1}\right)$ was expressed on a thermal time basis as follows:

$$
R G R=\frac{\left(\ln \left(W_{\mathrm{TT}_{2}}\right)-\ln \left(W_{\mathrm{TT}_{1}}\right)\right)}{T T_{2}-T T_{1}}
$$

where $W$ is the total plant fresh weight (g) and $T T$ the thermal time ( ${ }^{\circ} \mathrm{C}$ days). For consistency, the $R A R$ were also recalculated on a thermal time basis. Similarly, relative uptake rate of $\mathrm{P}\left(R U R\right.$ in $\mathrm{g} \mathrm{P} \mathrm{g}^{-1} \mathrm{P}$ $\left.\left({ }^{\circ} \mathrm{C} \text { days }\right)^{-1}\right)$ was calculated from $\mathrm{P}$ content as follows:

$$
R U R=\frac{\left(\ln \left(P_{\mathrm{TT}_{2}}\right)-\ln \left(P_{\mathrm{TT}_{1}}\right)\right)}{T T_{2}-T T_{1}}
$$

where $P_{\mathrm{TT} 1}$ and $P_{\mathrm{TT} 2}(\mathrm{~g} \mathrm{P})$ are amounts of $\mathrm{P}$ in the plant at thermal times $T T_{1}$ and $T T_{2}\left({ }^{\circ} \mathrm{C}\right.$ days $)$, respectively.

Assuming growth was exponential and according to Ingestad's theory [25-27], a plant which growth is limited by $\mathrm{P}$ availability is considered to be at a steady-state when the plant $\mathrm{P}$ concentration remains constant over time:

$$
\frac{\mathrm{d}(P / W)}{\mathrm{d} t}=0 \text {. }
$$

Under these conditions, it follows that:

$$
R U R=\frac{1}{P} \frac{\mathrm{d} P}{\mathrm{~d} t}=\frac{1}{W} \frac{\mathrm{d} W}{\mathrm{~d} t}=R G R .
$$

Phosphorus productivity $P_{\mathrm{P}}$ (growth rate per unit of phosphorus in the plant) was defined as the slope of the linear relationship between $R G R$ and plant $\mathrm{P}$ concentration $\left(C_{\mathrm{P}}=P / W\right)[24,26]$ :

$$
\frac{\mathrm{d} W}{\mathrm{~d} t} \times \frac{1}{W}=P_{\mathrm{P}} \times C_{\mathrm{P}}
$$

Moreover, when $\mathrm{P}$ availability limits $\mathrm{P}$ uptake, the steady state is obtained when $R U R$ is controlled by a numerically equal and constant relative addition rate $(R A R)$. Therefore, under steady-state conditions (constant $\mathrm{P}$ concentration in the plant), $R G R$ of a plant whose growth is limited by $\mathrm{P}$ availability equals $R U R$, and $R A R[25,26]$ :

$$
R A R=R U R=R G R .
$$

During the first days after seedling transplantation into the growth units, $R G R$ changed rapidly and reached a steady value. For each treatment, a period of constant $R G R$ was identified statistically, and non steady-state $R G R$ values were discarded. Light interception by seedlings was calculated according to Forseth and Norman [19]. Specifically, incident PPFD was partitioned into a direct and a diffuse component, respectively $Q_{\text {diff }}$ and $Q_{\text {dir. }} \cdot Q_{\text {dir }}$ was defined as the vertical downward photosynthetic photon flux density whereas $Q_{\text {diff }}$ was estimated as the average PPFD received from five angular sectors corresponding to four horizontal sectors and upward reflection. On average, measured $Q_{\text {dir }}$ and $Q_{\text {diff }}$ were $70 \%$ and $30 \%$ of the total incident PPFD, respectively .

The amount of direct light intercepted by sunlit foliage $\left(Q_{\mathrm{i}, \text { sun }}\right)$ was calculated as:

$$
Q_{\mathrm{i}, \text { sun }}=K \cdot Q_{\mathrm{dir}} \cdot F_{\text {sun }}
$$

where $\mathrm{K}$ was the foliar absorption coefficient calculated according to Campbell [6] with a mean inclination angle of the foliage plane from the horizontal, $\gamma$, assumed to be 45 degrees $(K=0.644)$, and $F_{\text {sun }}$ being the sunlit foliage area index calculated as:

$$
F_{\text {sun }}=\frac{1-\exp ^{\frac{-K F}{\cos (\theta)}}}{K \cdot \cos (\theta)}
$$

where $F$ was the foliage area index of each seedling $\left(\mathrm{cm}^{2} \mathrm{~cm}^{-2}\right)$ and $\theta$ was the zenith angle of the light source (assumed to be zero in our experiment). $F$ was given by equation (11), where $L$ was the total foliage area per seedling $\left(\mathrm{cm}^{2}\right.$ seedling $\left.{ }^{-1}\right)$ and $A$ the projected seedling foliage area on an horizontal surface $\left(\mathrm{cm}^{2}\right.$ seedling $\left.{ }^{-1}\right)$ estimated assuming the seedling foliage was entirely contained in a vertical cylinder with a radius $r$ given as $r=l \cos (\gamma)$ with $l$ being the average needle length so that:

$$
F=\frac{L}{A}
$$

Total foliage area per seedling was interpolated between measurements using the ratio of foliage area to stem height as estimated from destructive measurements and stem height values which were measured weekly during the experiment. The diffuse PPFD intercepted by both faces of foliage $\left(Q_{\mathrm{i}, \text { shade }}\right)$ was calculated as:

$$
Q_{\mathrm{i}, \text { shade }}=2 \cdot F \cdot Q_{\mathrm{diff}} \exp ^{\left(-0.5 F^{0.7}\right)}
$$

where 0.5 and 0.7 were coefficients depending on foliar orientation which account for the radiation extinction in the foliage [42].

The PPFD absorbed by a seedling $\left(Q_{\mathrm{a}}\right.$ mol seedling ${ }^{-1}$ day $\left.^{-1}\right)$ is given by:

$$
Q_{\mathrm{a}}=a \cdot A\left(Q_{\mathrm{i}, \text { sun }}+Q_{\mathrm{i}, \text { shade }}\right)
$$

where $a(=0.9)$ is needle absorbance in visible light [4].

Radiation-use efficiency ( $R U E$ in $\mathrm{g} \mathrm{DW} \mathrm{mol}{ }^{-1}$ ) was estimated as the slope of the linear regression between total dry biomass accumulated after seedling transplantation and photosynthetically active radiation absorbed $\left(c Q_{\mathrm{a}}\right)$ cumulated over the same period. Daily absorbed PPFD was calculated for five individual seedlings per treatment.

The six combinations of light and P levels could not be replicated. We therefore assumed the lack of a significant growth-unit effect. We took care to minimize the effects of the difference in temperature or incident light between growth units, and assumed the possible residual effects linked to a particular growth unit was unlikely to corrupt the large differences in the responses. Therefore, we considered each seedling as a replicate, though this is not in accordance with the strict statistical sense of a replicate. For most of the measured variables, twoway analysis of variance with interaction and linear regression based respectively on values measured on individual seedlings and averaged values per growth unit were performed using the ANOVA and GLM procedures of SYSTAT 10 for Windows (SPSS Inc. Chicago, USA). Significant differences between means were separated using the LSD procedure. The first order risk was fixed at $\alpha=0.05$.

\section{RESULTS}

\subsection{Relative Growth Rate $(R G R)$ in response to phosphorus and light}

A two-way analysis of variance showed that $R G R$ was significantly affected by $\mathrm{P}$ and light treatments and that a significant interaction existed between both factors (data not shown). At low light (LL), $R G R$ was unresponsive to $\mathrm{P}$ availability (Fig. 1). Conversely, at high light (HL), $R G R$ increased significantly with $\mathrm{P}$ availability between low (LP) and intermediate (IP) P levels, but not between IP and free access to P (HP) (Fig. 1). Under LP, $R G R$ did not differ significantly between light levels ( $\alpha>0.05$, tests not shown). Conversely, at IP and HP, $R G R$ increased significantly with increasing light level $(\alpha<0.05$, tests not shown). 
Table III. Mean values of the relative uptake rates (RUR in $\mathrm{mg} \mathrm{P}$ $\left.(\mathrm{mg} \mathrm{P})^{-1}\left({ }^{\circ} \mathrm{C} \text { day }\right)^{-1}\right)$ obtained during the steady state period for each light and $\mathrm{P}$ treatment. Mean values per treatment were obtained by averaging 3-4 individual values. For each light treatment, values annotated by the same letter are not significantly different (LSD test, $\alpha=0.05$ ).

\begin{tabular}{lcc}
\hline \multicolumn{2}{c}{$R U R$} \\
\hline HL & LL \\
\hline HP & $0.00730^{\mathrm{a}} \pm 0.00154$ & $0.00420^{\mathrm{a}} \pm 0.00057$ \\
IP & $0.00335^{\mathrm{b}} \pm 0.00038$ & $0.00272^{\mathrm{a}} \pm 0.00039$ \\
LP & $0.00101^{\mathrm{c}} \pm 0.00064$ & $0.00161^{\mathrm{b}} \pm 0.00043$ \\
\hline
\end{tabular}

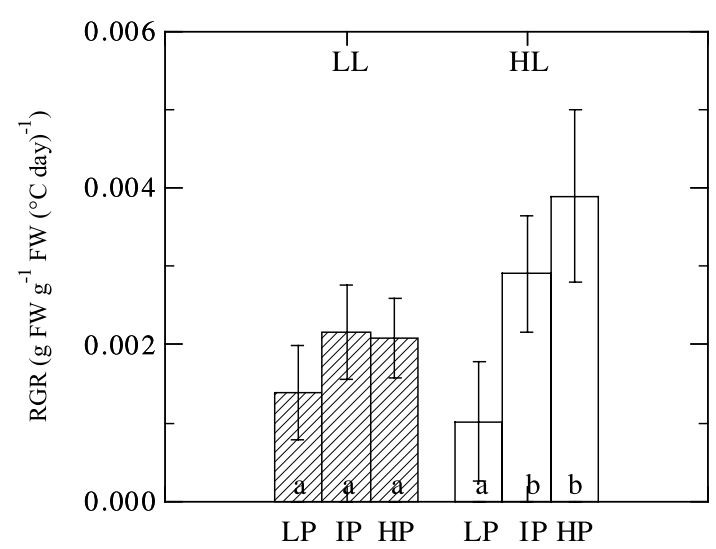

Figure 1. Relative growth rate $(R G R)$ of Pinus pinaster seedlings grown under three $\mathrm{P}$ regimes combined to two levels of irradiance: $\mathrm{LP}\left(R A R\right.$ of $\left.2 \mathrm{~g} \mathrm{P}(100 \mathrm{~g})^{-1} \mathrm{P} \mathrm{d}^{-1}\right)$, IP $\left(R A R\right.$ of $4 \mathrm{~g} \mathrm{P}\left(100 \mathrm{~g}^{-1} \mathrm{P} \mathrm{d}^{-1}\right)$ and $\mathrm{HP}$ (free access to P); HL (400-500 $\left.\mu \mathrm{mol} \mathrm{m}^{-2} \mathrm{~s}^{-1}\right)$ and LL (120$\left.180 \mu \mathrm{mol} \mathrm{m}^{-2} \mathrm{~s}^{-1}\right) . R G R$ was calculated on a thermal time basis. Mean values per treatment were obtained by averaging individual values of $R G R$ observed during the steady state period $(n=8-9$ individual values per treatment). For each light treatment, bars annotated with the same letter are not significantly different (LSD test, $\alpha=0.05$ ). Each vertical bar indicates the standard error of the mean.

\subsection{Relationships between relative growth rate $(R G R)$, relative uptake rate $(R U R)$ and relative addition rate $(\boldsymbol{R} A \boldsymbol{R})$}

A two-way analysis of variance showed that $R U R$ values were significantly affected by $P$ but not by light treatments (data not shown). Under high light (HL), RUR significantly increased from LP to IP and to HP (Tab. III). Under low light, $R U R$ significantly increased between LP and IP but not between IP and HP (Tab. III).

Figure 2 shows the relationships between $R G R, R U R$ and $R A R$ for all $\mathrm{P}$ and light treatments. $R A R$ could not be calculated for HP. $R A R$ was two fold larger at IP than under LP, as expected from the $\mathrm{P}$ addition treatments used. $R U R$ increased with $R A R$ under both high and low light treatments. Moreover, $R U R$ was close to $R A R$ for both LP and IP (Fig. 2). This demonstrates that at these P levels, $\mathrm{P}$ uptake was limited by $\mathrm{P}$ availability whatever the light availability. $R G R$ was close to $R U R$

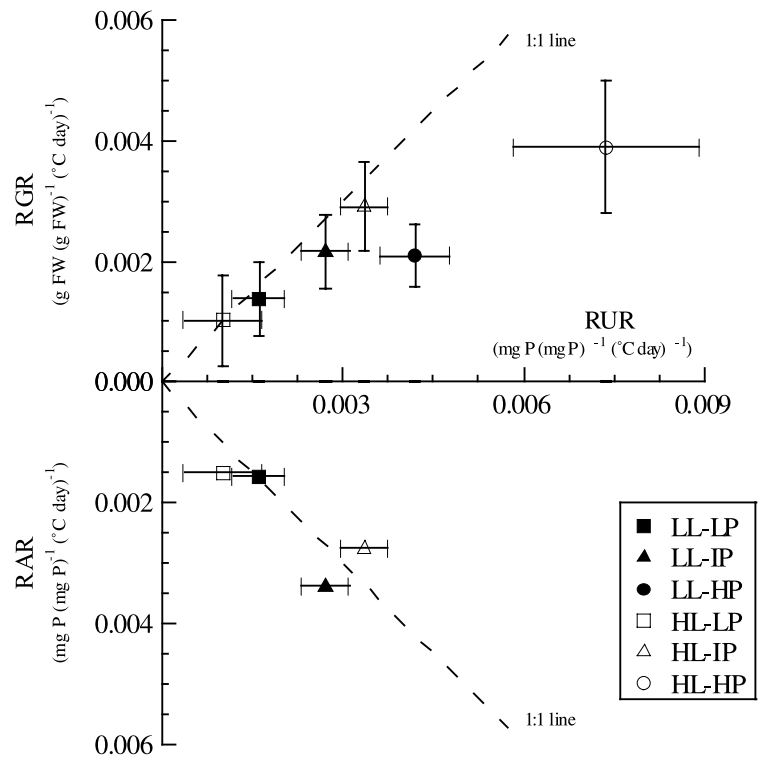

Figure 2. Relationships between relative growth rates $(R G R)$, relative uptake rates of $\mathrm{P}(R U R)$ and relative addition rates of $\mathrm{P}(R A R)$ for Pinus pinaster seedlings grown under two light levels (low light (LL) and high light (HL)) and three $\mathrm{P}$ regimes (low $\mathrm{P}(\mathrm{LP})$, intermediate $\mathrm{P}$ (IP) and high $\mathrm{P}(\mathrm{HP})$ ). Relative addition rates $(R A R)$ could not be calculated for the high $\mathrm{P}$ (free access) regime. $R G R, R U R$ and $R A R$ values were calculated on a thermal time basis. Mean values of $R G R$ and $R U R$ per treatment were obtained by averaging individual values of $R G R$ ( $n=8-9$ individual values per treatment) and individual values of $R U R(n=2-3$ individual values per treatment), respectively. Only individual values of $R G R$ and $R U R$ obtained during the steady state period were considered. Each vertical and horizontal bar indicates the standard error of the mean.

for LP and IP. However, RUR and RGR observed at HP deviated severely from the 1:1 relationship, suggesting that $\mathrm{P}$ uptake was no longer related to the increment in dry biomass. Indeed, $R U R$ for HP was larger than $R G R$ which demonstrates that growth was not controlled by $\mathrm{P}$ at this level and seedlings accumulated $P$ independently of growth. The incident light intensity was certainly below saturation at this stage and was likely the main limiting factor at HP.

Figure 3 shows the relationship between $R G R$ and plant $\mathrm{P}$ concentration, with the slope indicating the phosphorus productivity $\left(\mathrm{P}_{\mathrm{P}}\right)$. Under high light, $R G R$ increased sharply with increasing plant $\mathrm{P}$ concentration at LP and IP, and the slope of the linear relationship between plant $\mathrm{P}$ concentration and $R G R$, i.e., phosphorus productivity, was highest (Fig. 3). It levelled off at higher $\mathrm{P}$ concentrations where phosphorus productivity dropped. $R G R$ reached its maximum value $(0.0038 \mathrm{~g} \mathrm{FW}$ $\left.(\mathrm{g} \mathrm{FW})^{-1}\left({ }^{\circ} \mathrm{C} \text { day }\right)^{-1}\right)$ at an optimum $\mathrm{P}$ concentration between 0.002 and $0.004 \mathrm{~g} \mathrm{P}(\mathrm{g} \mathrm{DW})^{-1}$, close to the value found by Ericsson and Ingestad [17] in birch seedlings. Conversely, under low light, $R G R$ was independent of plant $\mathrm{P}$ concentration (Fig. 3). RGR did not increase with increasing plant $\mathrm{P}$ and no relationship was found between $\mathrm{P}$ accumulated by seedlings and growth. 


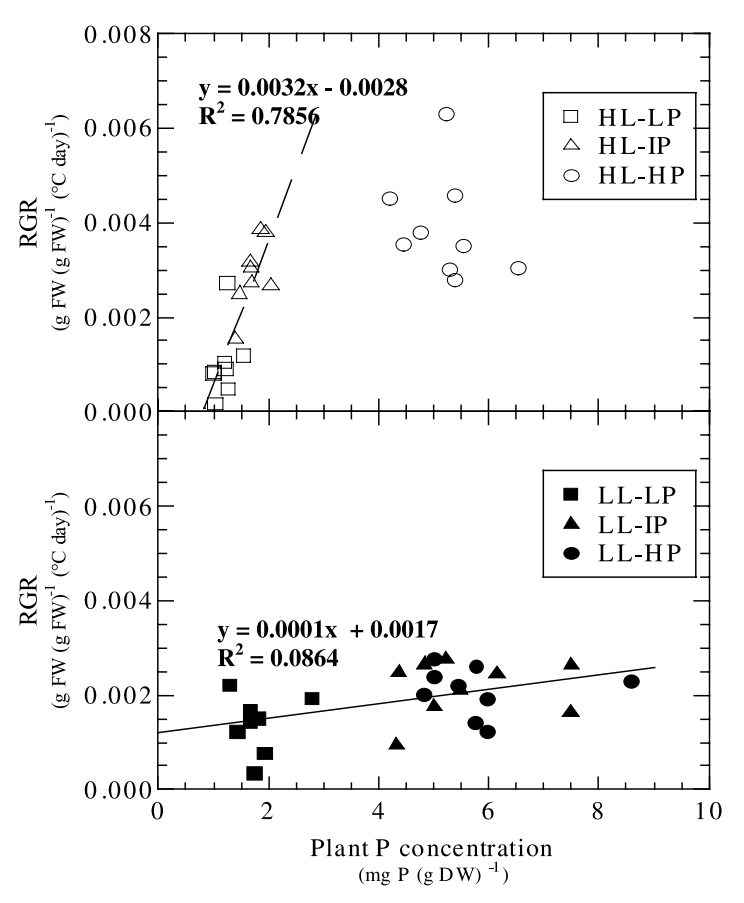

Figure 3. Relationships between relative growth rates $(R G R)$ and plant $\mathrm{P}$ concentration for Pinus pinaster seedlings grown under two light levels (high light (HL) and low light (LL)) and three $\mathrm{P}$ regimes (low P (LP), intermediate P (IP) and high P (HP)). Each symbol corresponds to one individual seedling.

\subsection{Leaf area development, PPFD absorbed and radiation use efficiency $(R U E)$}

Figure 4 shows the total leaf area per seedling calculated at the three sampling dates versus thermal time after transplantation. $\mathrm{P}$ availability affected leaf area development only under high light $(\alpha<0.05)$ (Fig. 4). At low light availability, $\mathrm{P}$ did not affect leaf area $(\alpha>0.05)$ (Fig. 4). Light availability affected leaf area development only at the highest P level $(\alpha<0.05)$. These results are consistent with those observed for $R G R$ (Fig. 1). At the end of the experiment, seedlings under HL and HP had the highest total leaf area $\left(132.8 \pm 33.9 \mathrm{~cm}^{2}\right)$, whereas seedlings in the HL-LP treatment had the lowest $\left(32 \pm 6.5 \mathrm{~cm}^{2}\right)$.

The relationships between total biomass (estimated at 105110 DAS) and absorbed irradiance cumulated per seedling for all light and $P$ treatments (Fig. 5) revealed an effect of the light level on the slope of the dry biomass - absorbed irradiance relationship, i.e., radiation use efficiency $(R U E)$. This indicates that seedlings grown under low light had higher RUE. Conversely, $\mathrm{P}$ treatments did not affect $R U E$. Indeed, under high light a unique linear relationship was observed for all $\mathrm{P}$ treatments between total biomass produced per seedling and cumulated absorbed irradiance. This demonstrates that under high light, growth was modulated by $\mathrm{P}$ nutrition via leaf area expansion rather than via a change in $R U E$.

The linear relationship between total biomass and absorbed irradiance had a steeper slope under low than under high light. In that case, the calculated absorbed irradiance was not very different among $\mathrm{P}$ treatments, since they did not affect leaf area,

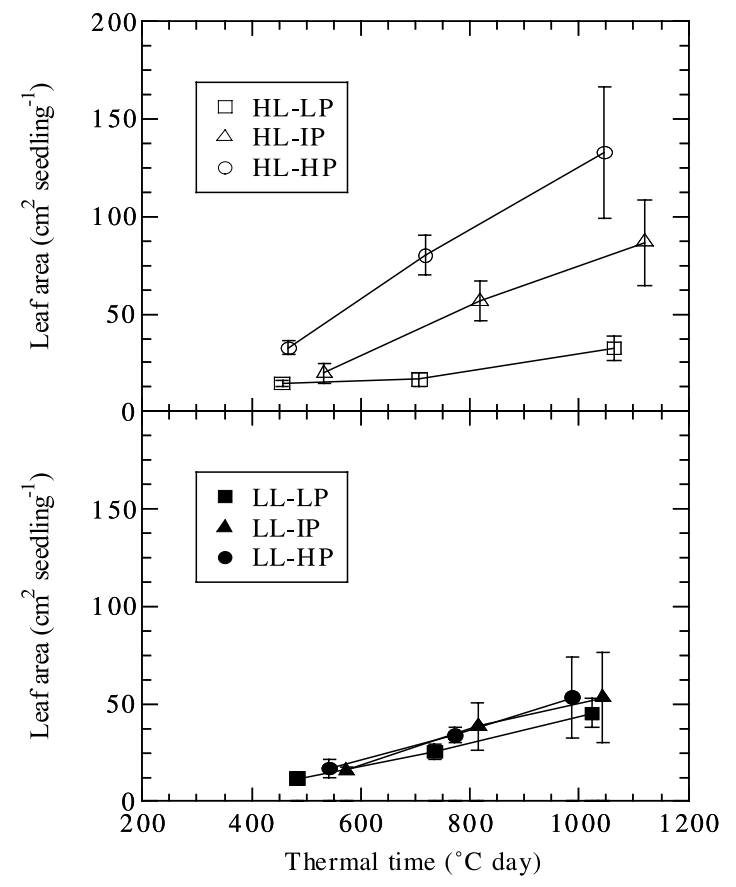

Figure 4. Total leaf area per plant of Pinus pinaster seedlings grown under two light levels (high light (HL) and low light (LL)) and three $P$ regimes (low $\mathrm{P}(\mathrm{LP})$, intermediate $\mathrm{P}$ (IP) and high $\mathrm{P}(\mathrm{HP})$ ). Mean values per sampling date and treatment were calculated by averaging 5-10 individual values. Each vertical bar indicates the standard error of the mean.

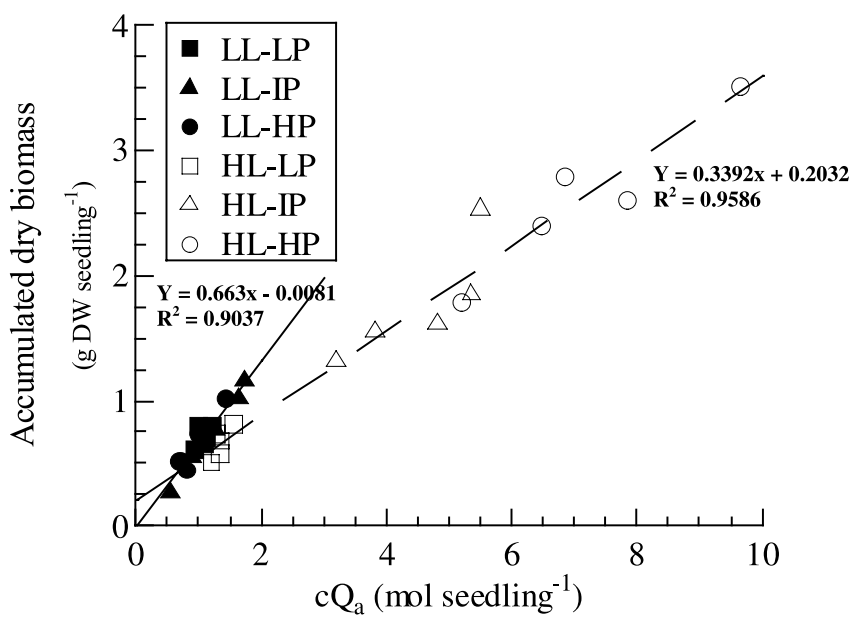

Figure 5. Relationship between the dry weight produced per seedling and the amount of absorbed irradiance $\left(c Q_{a}\right)$ for Pinus pinaster seedlings grown under two light levels (high light (HL) and low light (LL)) and three $\mathrm{P}$ regimes (low $\mathrm{P}$ (LP), intermediate $\mathrm{P}$ (IP) and high $\mathrm{P}(\mathrm{HP})$ ). Each symbol corresponds to one individual seedling harvested after 105-110 days.

resulting in the range of cumulated absorbed irradiance being mainly created by the within-treatment variability between seedlings. As for high light treatments, the relationship between cumulated absorbed irradiance and seedling biomass was the same for all $\mathrm{P}$ treatments. 


\section{DISCUSSION}

Our results reveal the occurrence of a complex interaction between phosphorus and light. At the lowest level of $P$ and light (LP-LL treatment), relative growth rate $(R G R)$ was enhanced only when both $\mathrm{P}$ and light were increased together, which means that the two factors were co-limiting. At higher levels of $\mathrm{P}$ (IP and HP), RGR increased with light, which means that light was the limiting factor. This result is consistent with the available knowledge on the photosynthetic requirements of Pinus pinaster [2, 3, 34]. Indeed, incident PPFD was 120 to $180 \mu$ mole $\mathrm{m}^{-2} \mathrm{~s}^{-1}$, which is far below the saturating PPFD for maritime pine [34].

Under the highest light level, $\mathrm{P}$ was limiting only under low $\mathrm{P}$ and intermediate $\mathrm{P}$, but not from IP to high $\mathrm{P}(\mathrm{HP})$. This lack of response to increasing $P$ availability between IP and HP may be explained by the fact that even under high light in our experiment (400-500 $\left.\mu \mathrm{mol} \mathrm{m} \mathrm{m}^{-2} \mathrm{~s}^{-1}\right)$, PPFD was not saturating and growth remained probably limited by light.

The differences in $R G R$ induced in our experiment were caused by the differential amount of intercepted radiation due to lower plant leaf area expansion in relationship with either $\mathrm{P}$ $[48,49]$ or light limitations rather than a reduced carbon assimilation rate (e.g., photosynthesis per unit of leaf area). In maritime pine, Ben Brahim et al. [2] have reported that under moderate $\mathrm{P}$ deficiency (between 0.0013 and $0.0017 \mathrm{~g} \mathrm{P}$ per $\mathrm{g}$ dry matter in plants), the lower plant growth was paralleled by a slower development of the foliage. Under more severe P deficiencies (between 0.0004 and $0.0013 \mathrm{~g}$ P per g dry biomass) a tight negative correlation was observed between phosphorus leaf concentration and photosynthetic capacity [15, 34]. Our experiment was conducted in the intermediate range of $\mathrm{P}$ deficiencies, so that the absence of effect of $\mathrm{P}$ treatments on $R U E$ is consistent with these results. Pine seedlings adjust to moderate phosphorus limitation mainly by changing their morphology (leaf area, dry-mass partitioning) while biochemical and photochemical limitations of photosynthesis would play a secondary role, if any. We conclude that leaf area and consequently the amount of light absorbed by seedlings was the main process limiting the carbon gain and dry matter increment for seedlings grown under mild $\mathrm{P}$ deficiency. Similar conclusions were produced for other plant species where low $\mathrm{P}$ was found to have a larger impact on leaf area expansion than on the rate of photosynthesis per unit leaf area $[14,20,45]$. Thus, a moderate $P$ deficiency affects the morphological component, while severe deficiencies mainly affect the physiological component. In a meta-analysis of literature based on 75 observations, it was reported that on average the morphological component of $R G R$ was more important than the "physiological" component in explaining the effects of nutrient limitation on growth [44].

Resource use efficiency was always highest at the lowest $P$ availability and decreased as the resource concentration increased. In the case of phosphorus, the decrease in phosphorus productivity at high level of $\mathrm{P}$ availability may be attributed to a growth independent accumulation, which may be interpreted as $\mathrm{P}$ storage. In our experiment, growth independent $\mathrm{P}$ consumption was observed in the $P$ free-access treatments. This can be attributed to the accumulation of inorganic phosphorus (Pi) in the vacuole $[32,46]$ and to a higher concentration of $\mathrm{P}$ incorporated in organic compounds in the cell as polyphosphate or phytate [13]. This ability may be ecologically important in enabling plants to face seasonal variations in phosphorus availability observed in the field [10]. Luxury consumption and large vacuolar storage are interpreted as potentially contributing to future productivity by several authors $[35,39]$. P remains in its oxidised form and a relatively large part is incorporated in structural cell components, such as phospholipids and nucleic acids. A smaller fraction of $\mathrm{P}$ is used as a component of the machinery of the plant's energy metabolism, where it is incorporated into glycolysis and the Calvin cycle [36, 37]. This growth independent accumulation of $\mathrm{P}$, i.e. lower phosphorus productivity, observed under low light conditions was also interpreted as a potential storage of $\mathrm{P}$ for red pine seedlings grown under $190 \mu \mathrm{mol} \mathrm{m} \mathrm{m}^{-2} \mathrm{~s}^{-1}$ [17]. The lack of growth response to nutrient under low light conditions has also been reported for beech seedlings [38] and other trees species [7].

The decrease of radiation use efficiency with increasing PPFD may be primarily explained by a decrease in quantum use efficiency, a well-documented characteristic of photosynthesis in C3 plants, an enhancement in respiration due to higher plant temperature may also have played a secondary role. It may be noted that $R U E$ was calculated to account for intercepted and not incident light, so that increased self shading cannot be invoked as an explanation of the decrease in $R U E$ with increasing plant size.

The calculated $R U E$ obtained in our experiment $(0.3-0.4$ (HL) to $0.6-0.7$ (LL) g DW mol ${ }^{-1}=2.8-3.8$ to $5.7-6.6 \mathrm{~g} \mathrm{DW}$ $\mathrm{MJ}^{-1}$ ) were higher than values found by numerous authors for several pine species $\left(1.3-1.9 \mathrm{~g} \mathrm{MJ}^{-1}\right)$ [8, 23, 30, 53]. Indeed, in the literature, studies on seedlings and mature trees predominantly calculated $R U E$ on the basis of the above ground dry matter production, whereas we expressed $R U E$ as the total dry matter production per MJ. Consequently, our $R U E$ values were higher than those reported in the literature, since the seedling root dry mass accounted for between 20 and $40 \%$ of total dry mass (for high $\mathrm{P}$ treatments and low $\mathrm{P}$ treatments, respectively).

Acknowledgements: We gratefully acknowledge the technical assistance provided by Régis Burlett and Michel Sartore during the study. This research was part of a project funded by the Réseau de l'Écophysiologie de l'Arbre (INRA). During her Ph.D. thesis work, the senior author was supported jointly by the Institut National de la Recherche Agronomique (INRA) and the Région-Aquitaine.

\section{REFERENCES}

[1] Albaugh T.J., Allen H.L., Dougherty P.M., Kress L.W., King J.S., Leaf area and above-and below ground growth responses of loblolly pine to nutrient and water additions, For. Sci. 44 (1998) 317-327.

[2] Ben Brahim M., Effets de la nutrition phosphatée sur la croissance et le bilan de carbone des jeunes plants de Pin maritime, Thèse, Université Henri Poincaré Nancy I, 1996.

[3] Ben Brahim M., Loustau D., Gaudillère J.P., Saur E., Effects of phosphate deficiency on photosynthesis and accumulation of starch and soluble sugars in 1-year-old seedlings of maritime pine (Pinus pinaster Aït.), Ann. Sci. For. 53 (1996) 801-810.

[4] Berbigier P., Bonnefond J.M., Measurement and modelling of radiation transmission within a stand of maritime pine (Pinus pinaster), Ann. Sci. For. 52 (1995) 23-42. 
[5] Brooks A., Effects of phosphorus nutrition on ribulose-1,5-biphosphate carboxylase activation, photosynthetic quantum yield and amounts of some Calvin-cycle metabolites in spinach leaves, Aust. J. Plant Physiol. 13 (1986) 221-237.

[6] Campbell G.S., Extinction coefficients for radiation in plant canopies calculated using an ellipsoidal inclination angle distribution, Agric. For. Meteorol. 36 (1986) 317-321.

[7] Canham C.D., Berkowitz A.R., Kelly V.R., Lovett G.M., Ollinger S.V., Schnurr J., Biomass allocation and multiple resource limitation in tree seedlings, Can. J. For. Res. 26 (1996) 1521-1530.

[8] Cannell M.G.R., Sheppard L.J., Milne R., Light use efficiency and woody biomass production of poplar and willow, Forestry 61 (1988) 125-136.

[9] Chang S.X., Seedling sweetgum (Liquidambar styraciflua L.) halfsib family response to $\mathrm{N}$ and $\mathrm{P}$ fertilization: growth, leaf area, net photosynthesis and nutrient uptake, For. Ecol. Manage. 173 (2003) 281-291.

[10] Chapin F.S.III, The mineral nutrition of wild plants, Annu. Rev. Ecol. Syst. 11 (1980) 233-260.

[11] Chartier M., Bonchretien P., Allirand J.M., Gosse G., Utilisation des cellules au silicium amorphe pour la mesure du rayonnement photosynthétiquement actif (400-700 nm), Agronomie 9 (1989) 281-284.

[12] Chen H.Y.H., Klinka K., Survival, growth, and allometry of planted Larix occidentalis seedlings in relation to light availability, For. Ecol. Manage. 106 (1998) 169-179.

[13] De Groot C.C., Van den Boogaard R., Marcelis L.F.M., Harbinson J., Lambers H., Contrasting effects of $\mathrm{N}$ and $\mathrm{P}$ deprivation on the regulation of photosynthesis in tomato plants in relation to feedback limitation, J. Exp. Bot. 54 (2003) 1957-1967.

[14] De Groot C.C., Marcelis L.F.M., Van den Boogaard R., Lambers H., Growth and dry-mass partitioning in tomato as affected by phosphorus nutrition and light, Plant Cell Environ. 24 (2001) 1309-1316.

[15] Delzon S., Bosc A., Cantet L., Loustau D., Variation of the photosynthetic capacity across a chronosequence of maritime pine correlates with needle phosphorus concentration, Ann. For. Sci. 62 (2005) 537-543.

[16] Elliot K.J., White A.S., Effects of light, nitrogen, and phosphorus on red pine seedling: growth and nutrient use efficiency, Ann. For. Sci. 40 (1994) 47-58.

[17] Ericsson T., Ingestad T., Nutrition of birch seedlings at varied realtive phosphorus addition rates, Physiol. Plant. 72 (1988) 227-235.

[18] Fan Z., Moore J.A., Wenny D.L., Growth and nutrition of container-grown ponderosa pine seedlings with controlled-release fertiliser incorporated in the root plug, Ann. For. Sci. 61 (2004) 117-124.

[19] Forseth I.N., Norman J.M., Modelling of solar irradiance, leaf energy budget and canopy photosynthesis, in: Hall D.O., Scurlock J.M.O., Bolhàr-Nordenkampf H.R., Leegood R.C., Long S.P. (Eds.), Photosynthesis and production in a changing environment, a field and laboratory manual, Chapman and Hall, London, 1993, pp. 207219.

[20] Fredeen A.L., Rao I.M., Terry N., Influence of phosphorus nutrition on growth and carbon partitioning in Glycine max, Plant. Physiol. 89 (1989) 225-230.

[21] Gelpe J., Lefrou G., Essai de fertilisation minérale sur pin maritime à Mimizan (Landes), résultats après la $26^{\mathrm{e}}$ année, Rev. For. Fr. 38 (1986) 394-400.

[22] González-Ochoa A.I., de las Heras J., Torres P., Sánchez-Gómez E., Mycorrhization of Pinus halepensis Mill. and Pinus pinaster Aiton seedlings in two commercial nurseries, Ann. For. Sci. 60 (2003) 43-48.

[23] Grace J.C., Jarvis P.G., Norman J.M., Modelling the interception of solar radiant energy in intensively managed stands, N. Z. J. For. Sci. 17 (1987) 193-209.

[24] Ingestad T., Mineral nutrient requirements of Pinus silvestris and Picea abies seedlings, Physiol. Plant. 45 (1979) 373-380.
[25] Ingestad T., Relative addition rate and external concentration; driving variables used in plant nutrition research, Plant Cell Environ. (1982) 443-453.

[26] Ingestad T., Lund A.B., Theory and techniques for steady state mineral nutrition and growth of plants, Scand. J. For. Res. 1 (1986) 439-453.

[27] Ingestad T., Agren G.I., Theories and methods on plant nutrition and growth, Physiol. Plant. 84 (1992) 177-184.

[28] Jacob J., Lawlor D.W., In vivo photosynthetic electron transport does not limit photosynthetic capacity in phosphate-deficient sunflower and maize leaves, Plant Cell Environ. 16 (1993) 785-795.

[29] Jose S., Merritt S., Ramsey C.L., Growth, nutrition, photosynthesis and transpiration responses of longleaf pine seedlings to light, water and nitrogen, For. Ecol. Manage. 180 (2003) 335-344.

[30] Kiniry J.R., Biomass accumulation and radiation use efficiency of honey mesquite and eastern red cedar, Biomass Bioenergy 15 (1998) 467-473.

[31] Lascoux D.M., Paino E.N., De Gardo R.S., Kremer A., Dormling I., Maturation of maritime pine (Pinus pinaster Aït.) seedlings after exposure to a period of continuous light, Tree Physiol. 12 (1993) 363-378.

[32] Lauer M.J., Blevins D.G., Sierzputowska-Gracz H., ${ }^{31}$ P-Nuclear magnetic resonance determination of phosphate compartmentation in leaves of reproductive soybeans (Glycine max L.) as affected by phosphate nutrition, Plant Physiol. 89 (1988) 1331-1336.

[33] Lewis J.D., Griffen K.L., Thomas R.B., Strain B.R., Phosphorus supply affects the photosynthetic capacity of loblolly pine grown in elevated carbon dioxide, Tree Physiol. 14 (1994) 1229-1244.

[34] Loustau D., Ben Brahim M., Gaudillère J.P., Dreyer E., Photosynthetic responses to phosphorus nutrition in two-year-old maritime pine seedlings, Tree Physiol. 19 (1999) 707-715.

[35] Margolis H.A., Brand D.G., An ecophysiological basis for understanding plantation establishment, Can. J. For. Res. 20 (1990) 375390.

[36] Marschner H., Mineral Nutrition of Higher Plants, Academic Press, 1995, London.

[37] Mengel K., Kirkby E.A., Principles of plant nutrition, International Potash Institute Worblaufen, Bern, 1987.

[38] Minotta G., Pinzauti S., Effects of light and soil fertility on growth, leaf chlorophyll content and nutrient use efficiency of beech (Fagus sylvatica L.) seedlings, For. Ecol. Manage. 86 (1996) 61-71.

[39] Mooney H.A., Gulman S.L., Constraints on leaf structure and function in reference to herbivory, BioScience 32 (1982) 198-206.

[40] Nguyen A., Dormling I., Kremer A., Characterization of Pinus pinaster seedling growth in different photo-and thermoperiods in a phytotron as a basis for early selection, Scand. J. For. Res. 10 (1995) 129-139.

[41] Nordborg F., Nilsson U., Growth, damage and net nitrogen uptake in Picea abies (L.) Karst. seedlings, effects of site preparation and fertilisation, Ann. For. Sci. 60 (2003) 657-666.

[42] Norman J.M., Simulation of microclimates, in: Hatfield J.L., Thomason I.J. (Eds.), Biometeorology and integrated pest management, Academic Press, New York, 1989, pp. 65-99.

[43] O'Neill J.V., Webb R.A., Simultaneous determination of nitrogen, phosphorus, and potassium in plant material by automatic methods, J. Sci. Fd. Agric. 21 (1970) 217-219.

[44] Poorter H., Nagel O., The role of biomass allocation in the growth response of plants to different levels of light, $\mathrm{CO}_{2}$, nutrients and water: a quantitative review, Aust. J. Plant Physiol. 27 (2000) 595-607.

[45] Rao M., Terry N., Leaf phosphate status, photosynthetic, and carbon partitioning in sugar beet, Plant Physiol. 90 (1989) 814-819.

[46] Ratcliffe R.G., In vivo NMR studies of higher plants and algae, Adv. Bot. Res. 20 (1994) 43-123.

[47] Rincon E., Huante P., Growth responses of tropical deciduous tree seedlings to contrasting light conditions, Trees Struct. Funct. 7 (1993) 202-207. 
[48] Rodriguez D., Keltjens W.G., Goudriaan J., Plant leaf area expansion and assimilate production in wheat (Triticum aestivum L.) growing under low phosphorus conditions, Plant. Soil 200 (1998) 227-240.

[49] Sato A., Oyanagi A., Wada M., Effect of phosphorus content on the emergence of tillers in wheat cultivars, JARQ 30 (1996) 27-30.

[50] Saur E., Effet de l'apport de phosphore, de carbonate de calcium et d'oligo-éléments $(\mathrm{Cu}, \mathrm{Mn}, \mathrm{Zn}, \mathrm{B})$ à trois sols sableux acides sur la croissance et la nutrition de semis de Pinus pinaster Soland in Aït. Croissance et nutrition en éléments majeurs, Agronomie 9 (1989) 931-940.

[51] Saur E., Influence d'une fertilisation cuprique et phosphatée sur la croissance et la nutrition minérale du pin maritime (Pinus pinaster Soland in Aït.) en sol sableux riche en matière organique, Ann. Sci. For. 47 (1990) 67-74.

[52] Sheriff D.W., Nambiar E.K.S, Fife D.N., Relationships between nutrient status, carbon assimilation and water use efficiency in Pinus radiata needles, Tree Physiol. 2 (1986) 73-88.
[53] Stockle C.O., Kiniry J.R., Variability in crop radiation-use efficiency associated with vapor-pressure deficit, Field Crops Res. 25 (1990) 171-181.

[54] Timbal J., Crémière L., Najar M., Becker M., Réponse à la fertilisation phosphatée d'un peuplement adulte de pins maritimes des Landes de Gascogne, Rev. For. Fr. 51 (1999) 671-677.

[55] Topa M.A., Cheeseman J.M., Carbon and phosphorus partitioning in Pinus serotina seedlings growing under hypoxic and low-phosphorus conditions, Tree Physiol. 10 (1992) 195-207.

[56] Trichet P., Vauchel F., Bert D., Bonneau M., Fertilisation initiale et réitérée du pin maritime (Pinus pinaster At.) : principaux résultats de l'essai de Berganton, Rev. For. Fr. 52 (2000) 207-222.

[57] Utriainen J., Holopainen T., Responses of Pinus sylvestris and Picea abies seedlings to limited phosphorus fertilization and treatment with elevated ozone concentrations, Scand. J. For. Res. 17 (2002) 501-510.

[58] Walters M.B., Reich P.B., Are shade tolerance, survival, and growth linked? Low light and nitrogen effects on hardwood seedlings, Ecology 77 (1996) 841-853. 